\title{
The Big House
}




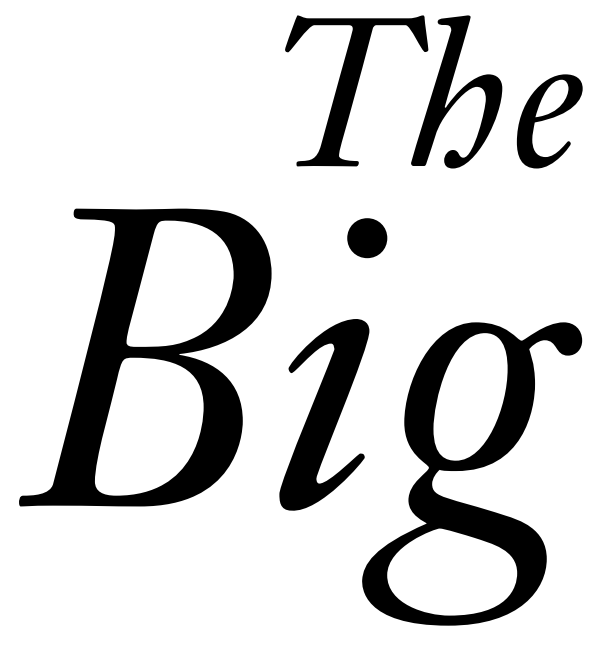

I M A G E A N D R E A L I T Y 


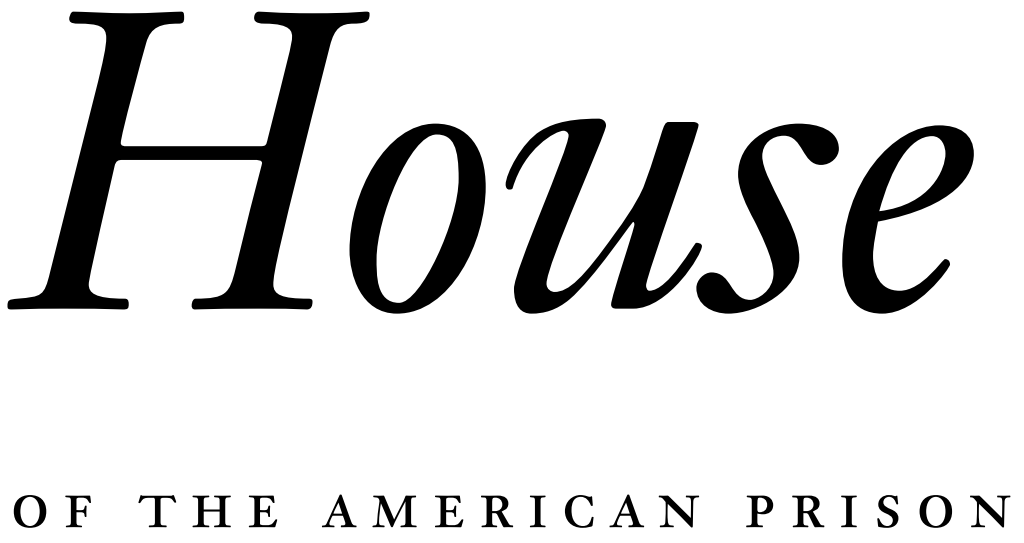

Stephen Cox 
Published with assistance from the foundation established in memory of Henry Weldon Barnes of the Class of 1882 , Yale College.

Copyright () 2009 by Stephen Cox.

All rights reserved.

This book may not be reproduced, in whole or in part, including illustrations, in any form (beyond that copying permitted by Sections 107 and 108 of the U.S. Copyright Law and except by reviewers for the public press), without written permission from the publishers.

Set in Janson type by Integrated Publishing Solutions. Printed in the United States of America.

Library of Congress Cataloging-in-Publication Data

Cox, Stephen, D.

The big house : image and reality of the American prison / Stephen Cox.

p. $\mathrm{cm}$. - (Icons of america)

Includes bibliographical references and index.

ISBN 978-0-300-I 24I9-4 (cloth : alk. paper) I. Prisons-United States.

2. Prisoners-United States. I. Title. HV9469.c694 2009 $365^{\prime} \cdot 973-\mathrm{dc22} \quad 2009008329$

A catalogue record for this book is available from the British Library.

This paper meets the requirements of ANSI/NISO Z39.48-1992 (Permanence of Paper).

IO $98 \begin{array}{lllllll} & 8 & 6 & 4 & 32 & \text { I }\end{array}$ 
Icons of America

\section{Mark Crispin Miller, Series Editor}

Icons of America is a series of short works written by leading scholars, critics, and writers, each of whom tells a new and innovative story about American history and culture through the lens of a single iconic individual, event, object, or cultural phenomenon.

Alger Hiss and the Battle for History, by Susan Jacoby

Frankly, My Dear: Gone with the Wind Revisited, by Molly Haskell Andy Warbol, by Arthur C. Danto

Fred Astaire, by Joseph Epstein

Gypsy: The Art of the Tease, by Rachel Shteir

The Hamburger: A History, by Josh Ozersky

Inventing a Nation: Washington, Adams, Fefferson, by Gore Vidal

King's Dream, by Eric J. Sundquist

Nearest Thing to Heaven: The Empire State Building and American

Dreams, by Mark Kingwell

Small Wonder: The Little Red Schoolhouse in History and Memory,

by Jonathan Zimmerman

Wall Street:America's Dream Palace,

by Steve Fraser

Forthcoming titles include:

Toni Bentley on George Balanchine's Serenade

Tom De Haven on Superman 
To Mebmet Karayel 